\title{
Factors Affecting the Decision to Use Just-In- Time Method for Precast Components in Surabaya Construction Industry
}

\author{
Vinza Firqinia Fristia ${ }^{1}$ and Trijoko Wahyu Adi ${ }^{1}$
}

\begin{abstract}
Lack of management of precast components lead to decreased productivity of work. The use of Just-In-Time (JIT) method in construction projects aimed to reduce production costs, improved quality, and increased productivity. However, not all construction companies implement JIT on the Surabaya construction project. This study aimed to identify factors that influence to use JIT method decisions for precast components in Surabaya construction company. Data from questionnaires were collected and analysed using RelativeImportance-Index analysis and Confidence-Interval. The results of research that Surabaya construction company have knew and understood but still not implemented. Factors that influence at construction project were planning and efficient communication between all stakeholders.
\end{abstract}

Keywords-Just In Time; Manager Project; Relative Importance Index; High Rise Building.

\section{INTRODUCTION}

The use of tool, material, and the way of working are considered to fulfill the quality of requirement if all requirements determined in the criteria and specification is fulfilled [9]. The choice of a method is so important in applying construction project because the appropriate implementation method can give the quality of the project from the view of financial or time. One of construction technology which offers some advantages for an easy implementation and economy is precast technology [1]. In applying precast method, the successful management is the key to achieve the expected quality [2]. JIT method can be performed to improve the system for achieving the expected quality of work. JIT philosophy comes from the manufacturing sector, helps to expedite the process of production through efficient material handling by providing the right material, in the amount, quality, and time for proper production [3]. JIT approach in construction can provide cost savings and increase productivity. It is also useful to urban conditions because it reduces the burden of transportation on traffic, reduces or eliminates the need for storage space at the construction site and be a solution in the case of space limitations [7]. The effectiveness of communication is one of the most significant factors for the successful implementation of JIT [8]. From the viewpoints of suppliers, JIT implementation in the construction industry will allow it to reduce uncertainty in demand and savings by minimizing storage [8]. There are seven main principles in the application of JIT method in the construction industry. It includes the material demand when it is

${ }^{1}$ Vinza Firqinia Fristia and Trijoko Wahyu Adi are with Departement of Civil Engineering, Institut Teknologi Sepuluh Nopember, Surabaya, 60111, Indonesia. E-mail: vinzafirqinia@gmail.com; Tri_joko@ce.its.ac.id. needed, top management commitment and employee involvement, eliminating activities which do not add the value, execution of work processes which are nondefective, the uninterrupted workflow, long term relationship among suppliers, and improvement by eliminating unproductive process [3].

Based on the preliminary survey conducted by researchers, it could be showed that $40 \%$ of respondents understand and perform the JIT method, and $40 \%$ of respondents have understood it but they did not apply that method. Besides, $20 \%$ of respondents did not understand the method of JIT. It can be concluded that the majority of construction projects in Surabaya city still does not implement the JIT method. Some managers of the project say that the use of JIT method aims to control project costs and the quality of materials. While other manager and engineer of the project do not use JIT method because of the lack of understanding and fear of the magnitude of the risk of time and cost of the project. Work culture and mindset of the contractors determine their attitude to the decision of the use of JIT method. There are various aspects of management in the JIT method which could potentially be used in precast technology, but not all construction companies have implemented it. This study aimed to see what supporting and inhibiting factors which influence the decision of the project managers in the use of JIT method for precast components on a construction project in Surabaya city.

\section{METHOD}

The type of this research is explorative research which aims to collect data and information on the topic or new issues aimed for deeper or advanced research. The research population was the project manager in medium to large classes of Surabaya construction companies which incorporated in Indonesian Contractor Association. All respondents should be experienced in building construction and the use of precast components. Determination of the samples used in this study is a nonprobabilistic sample with Purposive sampling technique. As a consequence, there would be obtained 30 respondents project managers from 30 construction companies. The data collection is done by using primary data gotten from questionnaires and interviews to several respondents. The variable in this study was obtained from the literature review and the results of the previous research. The research variables are used based on the characteristics of the use of precast components and JIT method. The variables of this study are divided into two 
functions named supporting and inhibiting factors which influence the decision to use JIT (Table 1). Data collected through the questionnaire survey was analyzed by using validity and reliability test of questionnaires, descriptive analysis, one way ANOVA test, the relative importance index (RII), and the last stage of testing confidence interval (CI Test).

\section{RESUlT AND DISCUSSION}

\section{A. Overview of Respondents and the Research Object}

Things relate to the respondents in this study which need to be described is a long experience in the field of construction project. The longer working time and experiences of the respondents, of course, the more understand the ideology of the use of precast components in construction projects. (Figure 1). The contractors' experience influences their way in handling problems in the implementation process of work. The contractors who have experienced can easily cope with the problems which arise, surely it will be different from the contractors who lack of experience. They will require more time.

The majority of construction companies knows and understands JIT method (53\%) while those who do not know and do not understand the JIT method in construction projects is 3\% (Figure 2). Based on the results of the questionnaire, it could be seen that most of the construction companies do not apply JIT method (Figure 3). At construction project, the implementation of JIT method in the use of precast components of construction projects is done by a number of reasons (Table 2). The planning from the beginning of the project became the highest reason to decide the use of JIT method. The planning from beginning project is done very well with a suitable design for the use of precast components started from suitable forms, correct delivery time, and the quality at the time of installation. Thus, by applying a good planning, there is no excessive material at the project site, readiness to receive and install, and effective for a limited project site.

Based on the opinion of the manager project, the type of building project with the use of prefabricated components which suitable with JIT method is an apartment, hotel and mall (Figure 4). The urban environment which is very busy with limited project location makes JIT method as the alternative development. The use of correct precast components with the correct method will increase the productivity on the construction project. Type of material of the component is concrete $(28 \%)$, precast factory ready for installation (25\%), and steel (10\%). Concrete and Precast factory which is ready to be plugged is the highest possible choice made by JIT method because the material precast components are brought to exactly fit the needs and quality (Table 5).

\section{B. The Big Test Of The Influence Factors}

In this phase, RII test was conducted to determine the level of assessment or sequencing of the factors which influence the decision of the construction company in using JIT method. The result of RII showed the highest to lowest value. This RII value will range from 0 (minimum) to 1 (maximum), the closer to the 1 value, the more influential factors to the decision of JIT method in the construction company. The results showed that four (4) main factors supported the ratings of thirty (30) respondents while RII test results for five (3) main inhibiting factor on the rating. (Table 3 and Table 4).

C. Confidence Test sampels for usage decision factors of JIT

Confidence interval test is also done to support and strengthen research data and ranking results obtained from RII test. In this study, the discussion was conducted only on the variables included in the first rank. The variable in the first rank is a variable which is considered very influential and suitable with the existing conditions in the use of precast components work on the construction project by using of JIT method. It can be seen that the first rank was the simplification of the work processes to minimize labor with the use of fabrication technology, to reduce excess transport capacity with a precision schedule, the scope of work which is detailed and completely defined to control project costs, and counting the hours of work tools used. Furthermore, the first ranking in inhibiting factor is readiness of equipment which is not on time, poor layout planning of construction projects, and uncertainty of weather or environmental projects (Table 3 and Table 4).

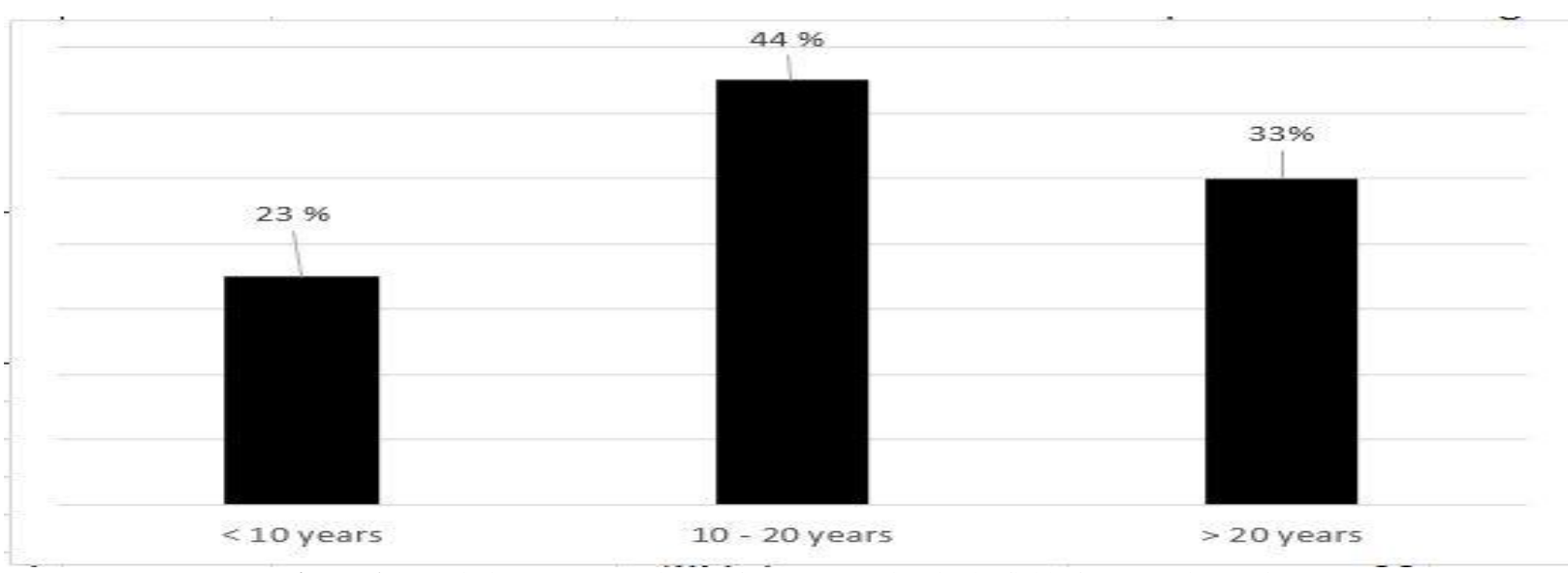

Figure. 1. Description Long Experience of Manager Project in the field of construction project. 
The $2^{\text {nd }}$ International Seminar on Science and Technology

August $2^{\text {nd }}$ 2016, Postgraduate Program Institut Teknologi Sepuluh Nopember, Surabaya, Indonesia

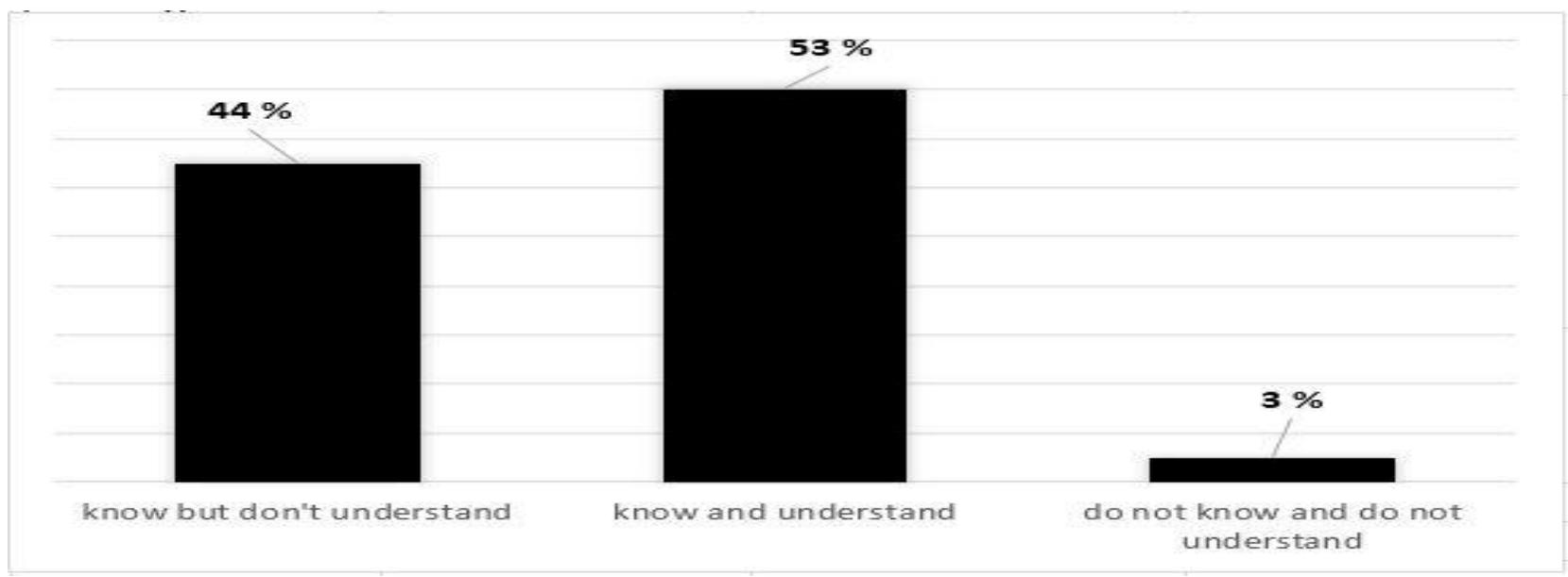

Figure. 2.Understanding The JIT method on overall Surabaya construction company

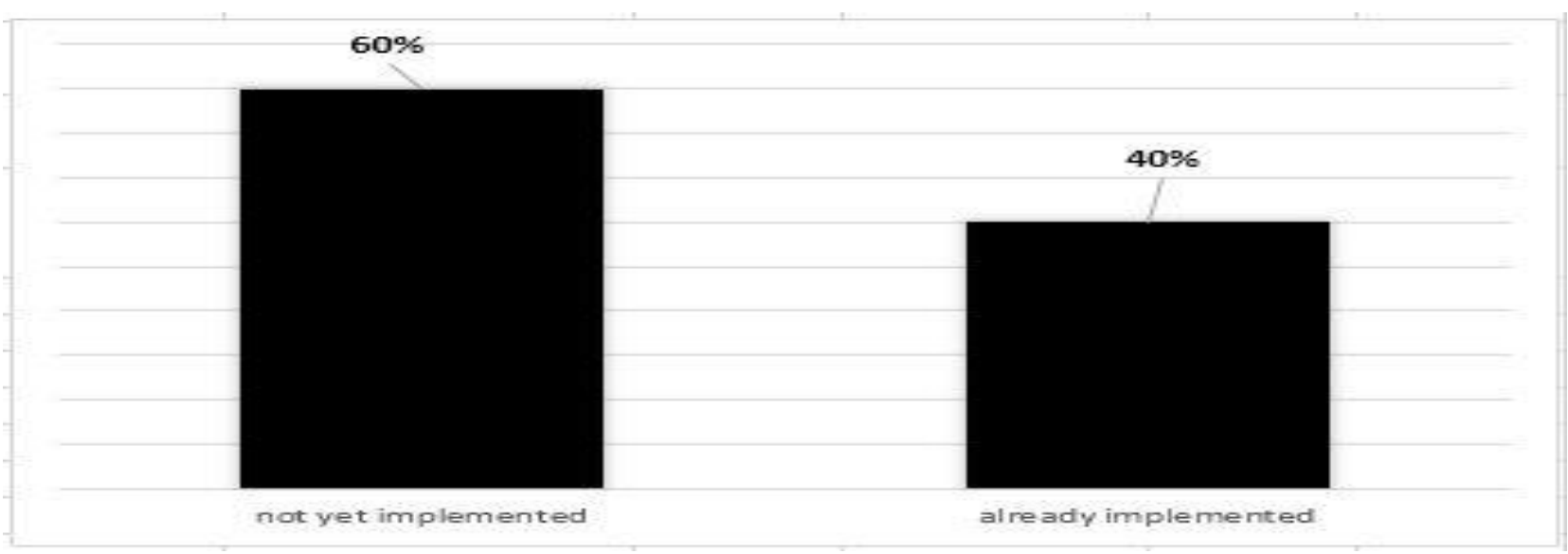

Figure. 3.Application of the JIT Method on overall Surabaya construction company

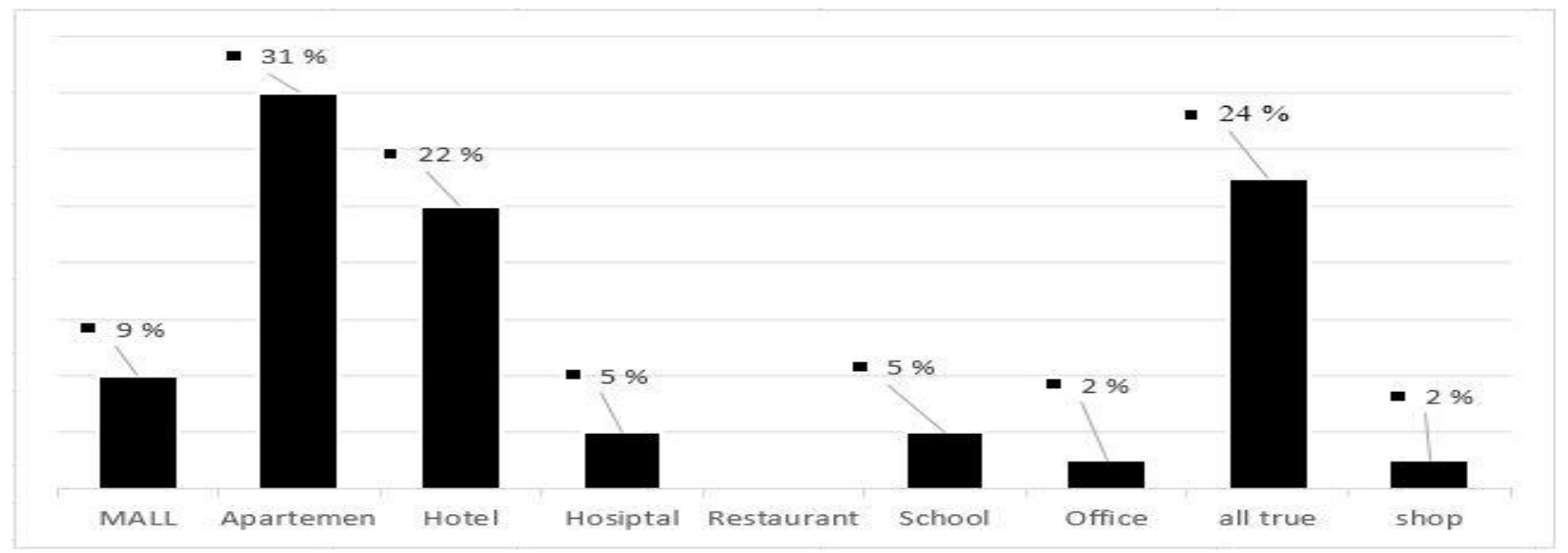

Figure. 4.Types building project with the use of precast components according to the JIT Method 
TABLE 1 .

VARIABLES INFLUENCING DECISIONS OF JIT METHOD

\begin{tabular}{|c|c|}
\hline \multicolumn{2}{|c|}{ Supporting Factors } \\
\hline $\begin{array}{l}\text { The company's policy to support the costs and technology in the } \\
\text { implementation of JIT }\end{array}$ & Getting suppliers: low cost and on time delivery \\
\hline $\begin{array}{l}\text { Controlling production quality control, cost control, and the amount of } \\
\text { production. }\end{array}$ & Getting suppliers: the ability to respond to needs \\
\hline Management of the material movement for limited land & The detailed and complete scope of work to control project costs \\
\hline $\begin{array}{l}\text { Facilitate the coordination of procurement planning system with } \\
\text { manpower and equipment, as well as financial planning and material } \\
\text { specification. }\end{array}$ & The existence of material control to change the scope of work \\
\hline $\begin{array}{l}\text { Top Management Support is responsible for controlling the management } \\
\text { of materials, and are committed JIT }\end{array}$ & $\begin{array}{l}\text { Facilitate the planning of purchase / delivery based on current } \\
\text { consumption at the project site }\end{array}$ \\
\hline $\begin{array}{l}\text { The involvement of field workers who maintain the quality of the } \\
\text { material, productive, and skilled coordinate }\end{array}$ & Hold a flexible contract with the supplier \\
\hline The simpler way of planning reporting techniques & The readiness of human resource to accept and install \\
\hline Makes it easy to define, select, calculate and control the material demand & Material transportation is more responsive and cheaper \\
\hline The smaller risk of material procurement & $\begin{array}{l}\text { Simplification of work processes to minimize the use of labor with } \\
\text { fabrication technology }\end{array}$ \\
\hline $\begin{array}{l}\text { The Grouping linked activities and sequential together at one location to } \\
\text { minimize motion handling }\end{array}$ & $\begin{array}{l}\text { The reduction of manpower due to a greater need of heavy } \\
\text { equipment. }\end{array}$ \\
\hline Reducing the size of bookings (purchase lot size) as its needed. & Getting suppliers: affordable location for delivery transportation \\
\hline Being able to reduce traffic congestion in the workplace & Getting suppliers: able to establish long-term partnership \\
\hline Reducing excess transport capacity with precision schedule & $\begin{array}{l}\text { Evaluating the feasibility of the components used through } \\
\text { contracts }\end{array}$ \\
\hline $\begin{array}{l}\text { Developing local supply chain with fewer sources of supply and establish } \\
\text { long-term partnership }\end{array}$ & $\begin{array}{l}\text { Controlling costs between the cumulative value of the budget } \\
\text { costs, the cost allocation plan and actual costs. }\end{array}$ \\
\hline Set the progress payments made in a contract & Estimating the hours of work tools used \\
\hline \multicolumn{2}{|c|}{ Inhibiting Factors } \\
\hline The Poor layout planning of construction projects & The unresponsive and unprepared transportation \\
\hline The readiness of equipment which is not on schedule & The low quality of the manufactured product \\
\hline The uncooperative attitude of purchasing agents and suppliers & The frequency of schedule changes \\
\hline The uncertainty of weather or environment project & The Unstable economic environment that canincrease price \\
\hline The Uncertainty demand due to lack of coordination with suppliers & The Lack of trust between managers and subordinates \\
\hline The risk of minimum Storage & $\begin{array}{l}\text { The Lack of experience and understanding among project } \\
\text { management for procuring } J I T\end{array}$ \\
\hline $\begin{array}{l}\text { The Poor materials procurement schedule which delay the flow of } \\
\text { material and buildup material }\end{array}$ & The Difficulties payment mechanism \\
\hline
\end{tabular}

TABLE 2.

REASON THE JUDGMENTS PROJECT MANAGER TO APPLY THE JIT METHOD TO USE PRECAST COMPONENTS

\begin{tabular}{lc}
\multicolumn{1}{c}{ Reason } & Level \\
\hline \hline Planning from the beginning of the projects & $64 \%$ \\
Limitations of the project site & $25 \%$ \\
Other : Environmental Conditions to set a time-efficient & $7 \%$ \\
Running out of project funds / manage cash flow & $4 \%$ \\
\hline \hline
\end{tabular}

TABLE 3 .

TOP RANKING OF SUPPORTING FACTORS

\begin{tabular}{lcc}
\hline \hline \multicolumn{1}{c}{ Variabels } & Score RII & $\begin{array}{c}\text { Rank of } \\
\text { CI }\end{array}$ \\
\hline $\begin{array}{l}\text { Simplifying work processes in order to minimize the labors by using } \\
\text { fabrication technology }\end{array}$ & 0.820 & 1 \\
$\begin{array}{l}\text { Reducing the excessive transport capacity with precision schedule } \\
\begin{array}{l}\text { The scope of work which is detailed and completely defined to control } \\
\text { project costs. }\end{array}\end{array}$ & 0.793 & 1 \\
Estimating the hours of work tools used & 0.793 & 1 \\
\hline \hline
\end{tabular}


TABLE 4.

TOP RANKING OF INHIBITING FACTORS

\begin{tabular}{lcc}
\hline \hline \multicolumn{1}{c}{ Reason } & Score RII & $\begin{array}{c}\text { Rank of } \\
\text { CI }\end{array}$ \\
\hline The readiness of equipment which is not on schedule & 0.800 & 1 \\
The poor layout planning of construction projects & 0.767 & 1 \\
The Uncertainty weather or environment project & 0.767 & 1 \\
\hline \hline
\end{tabular}

TABLE 5 .

MATERIAL FROM PRECAST COMPONENTS THAT ALLOW TO DO WITH THE JIT METHOD

\begin{tabular}{lr}
\hline \hline \multicolumn{1}{c}{ Material From Precast Components } & Prosentase \\
\hline Concrete & $28 \%$ \\
Steel & $10 \%$ \\
Aluminium & $9 \%$ \\
Glass & $9 \%$ \\
Iron & $5 \%$ \\
Raw materials : cement & $2 \%$ \\
Raw material : sand & $3 \%$ \\
Raw material : gravel or stone broke & $3 \%$ \\
Precast factory-ready to install & $25 \%$ \\
Material begisting & $2 \%$ \\
Wood multiplex & $2 \%$ \\
GRC & $2 \%$ \\
\hline \hline
\end{tabular}

\section{Discussion}

After analysis of the obtained data is 4 (four) supporting factors.

\section{1) Simplifying work processes in order to minimize the labors by using fabrication technology.}

The use of precast components becomes one alternative in the simplification of work processes. "JIT" is able to provide a smooth flow from the supplier to the customer. When the process is documented, the excessiveness can be eliminated. The elimination of this excessiveness will be able to simplify the process, which finally allows the product to flow through the various processes faster [6]. Most construction companies say that the material component which is allowed in "JIT" method are concrete and precast factory which are ready for installation. The material production process was fabricated at project outside and brought to project site for being used immediately. The use of precast components becomes a solution to the problem of inadequacy land and high traffic state in Surabaya. The selection of JIT method to the use of precast components supports the development of a strategic area in the city of Surabaya. The growth of office buildings in Surabaya are centralized in center of Surabaya as the core activity. Surabaya as one of the cities in East Java has a strategic role on a national scale as a service center activities of eastern Indonesia.

2) Reducing the excessive transport capacity with precision schedule

Precast component materials, which enable the JIT method, are concrete. The volume of concrete which are booked per concrete mixer truck must be matched. The main consideration in booking volume of concrete on each truck / orders are not exceeded the maximum limit of reservation and consider the condition of the road to be taken. Reducing excessive load of transportation capacity is needed in order to prevent the Surabaya road damage. It is able to control the availability of inventory. There are two types of inventory control systems, namely (1) the system fixed number of orders, and (2) fixed order cycle system [4]. When the system the number of orders is fixed, predetermined fixed amount will be booked when stocks declined to the point of the message (i.e. the amount which is expected to be used during the time of reservation). Although the number of orders remains, the time of the message is not uncertain. However, with a fixed order cycle system, the date of the message was made permanently and the ordered quantities depending on the usage of the previous orders given and the forecast for the time of booking.

3) The scope of work which is detailed and completely defined to control project costs

In the opinion of project managers of construction companies which have not applied this scope of work, it is able to expedite the flow of project activities on schedule, equipment, and labor. By the existing of these factors, it easily controls the planning of purchase / delivery of the appropriate current consumption and to cope with limited locations. One of the strategic measures which are necessary for the implementation of JIT is to define the chain of value-added work processes, then define work processes by using flow charts and line balancing process with the workforce and existing facilities. The detailed and complete scope of work will be able to detect the problems easily [4]. So, the flow of production will go smoothly and the reduction of the waiting time becomes the important aspect of JIT method. 4) Estimating the hours of work tools used

The plan from the beginning of the project that became the highest reason in deciding the method of JIT includes the exposure of the needs of lifting equipment / heavy 
which will be used. Experience and understanding of the project managers in using precast components and has been applying the calculation method JIT is able to provide the right equipment as needed so the waiting time is not too long. The control of the hours of work tools used will be able to reduce set-up time. The reduction of set-up time is an important aspect to achieve the successful implementation of JIT. Its reduction by shortening the waiting time and support time is needed to produce a wide variety of the units required at the time and the amount needed [4]. The Reduction of set-up time will facilitate the flow of activity with limited land Surabaya city projects.

Whereas for inhibiting factor, there are three (3) factors as follows.

a. The readiness of equipment which is not on schedule Every works which will be done must be in accordance with a predetermined schedule in order to avoid the ineffective and inefficient things. If the things are incompatible with the function, the works will be accumulated and delayed due in accordance with the implementation schedule. Based on the experience of project managers who have implemented JIT methods without the availability of equipment, it will postpone the assembly and the installation of components.

\section{b. The poor layout planning of construction projects}

One of the problems in the project in Surabaya is the distance between the facilities and the frequency with considerable displacement of workers which will greatly affect the productivity of workers. The irregularities of facility placement would endanger workers and make many people uncomfortable to pass it. Their losses from poor layout can hinder efficient operation, as the materials move slowly, handling cost is high because the more transfer / transport of materials, the production equipment and other facilities are arranged irregularly thus disrupting production, service area narrow and spaced far apart, the materials in the process are often damaged or lost, often encountered failure in completing production on time, and place of receipt of goods cannot be immediately emptied so that the goods arrival are slowed down [5]. The lack of planning of the layout of the production site at the project site with limited environmental conditions would delay the flow of material and buildup material.

\section{c. The Uncertainty weather or environment project}

Wet condition or rain tend to complicate control equipment, better mobilization carried out a location that will be done, the cause of the delay, and the quality of work that affect the cost of the project. [10]. The condition of Surabaya with relatively high rainfall will hinder the delivery and installation of precast components and equipment readiness. Precast component materials which enable the JIT method are concrete. Casting the concrete in the rain condition will make a concrete not reaching target quality.

\section{CONCLUSION}

Readily installed of precast factory are able to fill out the lack of manpower by the use of JIT method on apartment projects. Supporting factors of the decision to use JIT method for precast components in the construction project is the simplifying of the work scope through fabrication technology, and controlling use of materials and equipments efficiency. While the inhibiting factor of the decision to use JIT method is unpreparedness of equipment and layout planning of the project, and project environmental uncertainty. Thus, the implementation of JIT method in construction projects would be required an efficient planning and communication between all stakeholders.

\section{REFERENCES}

[1] Abduh, M. (2005). "Konstruksi Ramping: Maksimalkan Value dan Minimumkan Waste", Journal seminar nasional : Sustainability dalam bidang material, rekayasa, dan konstruksi beton, Fakultas Teknik Sipil dan Lingkungan, ITB: Bandung.

[2] Ervianto, W.I. (2006). Eksplorasi Teknologi dalam Proyek Konstruksi (Beton Pracetak dan Bekisting), penerbit : Andi, Yogyakarta.

[3] Low, S.P. and Chan, Y.M. (1997). "Managing Productivity in Construction JIT Operations and Measurements". Brookfield,Vt: Ashgate Publishing Co.

[4] Ristono, A. (2009). Sistem Produksi Tepat Waktu. Yogyakarta: GrahaIlmu.

[5] Heizer, J., \& Render, G. (2004). Principles of operations_management. New Jersey: Prentice Hall.

[6] Viale. (2000). library.upnvj. Retrieved from Bab II Tinjauan Pustaka Hasil Penelitian: http://library.upnvj.ac.id.

[7] Malyavin, I. (2014). "Supply Chain Management: Just-In-time logistic in construction". Journal of Auckland univeristy of technology, published: Auckland, 10.

[8] Akintoye. (1995). RMB 511 Case Study: Innovation In The Malaysian Housing Industry. 21042171-Just-In-TimeConstruction-Method, 72.

[9] Saada, B. (2015, Maret 13). Manajemen Kulitas dalam proyek konstruksi. Retrieved November 11, 2015, from https://ecodrain.wordpress.com.

[10] Aji, D. (2011, April 30). Desain Rumah, Kontraktor Bangunan Developer dan Pengadaan Barang. Retrieved from dadiaji wordpress: https://dadiaji.wordpress.com. 